\title{
Root System Morphology Influences Lateral Stability of Swietenia mahagoni
}

\author{
Edward F. Gilman and Chris Harchick
}

\begin{abstract}
Propagation containers modify root systems, which affect post-planting anchorage in reforestation efforts, but little is known about larger-sized trees typical in urban landscapes. The main goal of this study was to determine the role of root morphology on postplanting anchorage and growth on Swietenia mahagoni (L.) Jacq., a common landscape tree in warm climates. Two propagation container types, two larger container types, and root pruning were used to impose various root morphologies inside root balls. Anchorage was evaluated by winching trees at two bending stresses to simulate wind events. Interaction between propagation container type and root pruning when the liner was shifted into $3.8 \mathrm{~L}$ containers prevented either from consistently influencing anchorage. Trunk tilt (i.e., instability) immediately following pulling was greatest for trees with the most root CSA deflected by the $9.5 \mathrm{~L}$ container; trees with straighter main roots in the root ball were better anchored. Researchers found seven root attributes associated with trunk tilt during winching tests that evaluated anchorage. Results show that straight roots in the root ball were associated with stable trees after planting into field soil.

Key Words. Anchorage; Bending Stress; Deflected Roots; Root Depth; Stability; Straight Roots; Swietenia mahagoni.
\end{abstract}

Root deformations caused by deflection in the propagation container can lead to poor rooting out, resulting in unstable trees (Lindgren and Örlander 1978). For example, Scots pine (Pinus sylvestris L.) trees developed spiraling roots when in $75 \mathrm{ml}$ propagation containers, causing them to be less stable in the soil seven to nine years after planting compared to naturally regenerated trees (Lindström et al. 2005). Other root defects, such as downward deflected roots, were later recognized as causing problems with stability following planting jack pine (Pinus banksiana Lamb.) (Chapman and Colombo 2006). Many studies on conifer seedlings show that root deflection in propagation containers can contribute to long-term growth problems after planting in the forest (Krasowski 2003). Roots on shade trees in larger containers also deflect around or downward and proliferate at the bottom of containers (Marshall and Gilman 1998), probably because of suitable air, nutrition, and water at the bottom, but the impacts on health and anchorage are poorly documented.

Selby and Seaby (1982) attributed poor anchorage of out-planted pines to a dearth of lateral support roots. The root segment growing against the container wall can suberize when retained in containers for too long, thus losing the capacity to generate secondary roots. This results in aggressive root growth primarily from the bottom of the container once planted into soil (Salonius et al. 2000). For this reason, Lindström et al. (2005) tested a stabilized or reinforced substrate that could be removed easily from the container 8-12 weeks after seed germination, thus preventing most container-induced root deflections. Burdett (1990) tested a mesh-walled container that encouraged roots to be distributed evenly along the sides of the liner root ball due to air-pruning at the bottom. A number of growers still use these today. Rooted cuttings in coppertreated containers in one representative study produced a greater percentage (40\%) of roots in the top one-third of the liner compared to trees grown in untreated containers $(18 \%)$; there were also more roots in the interior of the root ball and fewer on the outside forming an imprint (Smith and McCubbin 1992). Root pruning liners as they were shifted into a larger container has been associated with a substantial increase in the number of straight roots inside the root ball (Gilman et al. 2010); however, there are few studies evaluating anchorage. 
Reduced anchorage of trees from nursery containers compared to trees transplanted from a field nursery is attributable to a combination of root deflection in the containers, less root ball mass, and low root ball soil strength due to voids created by decomposition of the organic substrate typical of containergrown trees (Gilman and Masters 2010; Gilman et al. 2013). Although relative contribution was not assigned to each of these three attributes, previous models developed in forest stands suggest that rootsoil plate depth, shape, and mass were responsible for a significant $(13 \%-45 \%)$ portion of overturning resistance (Coutts 1983; Ennos 1995). Roots growing in the windward direction (Stokes 1999) and the location of the rotation axis (hinge point), among other factors, also contribute (Fourcaud et al. 2008).

Though advances have been made in describing anchorage mechanics on trees planted from small propagation-sized root balls typical of plantations, few studies have been performed on trees planted from the much larger root balls typical in urban landscapes. The strategy of growing roots radially away from the base of the trunk, instead of deflecting down, up, or around, appears wellsuited for binding together a large mass of soil and roots into a root-soil plate that resists overturning (Gilman et al. 2010b; Gilman et al. 2013). Root diameter decreases suddenly at the transition point of one container to the next larger size because roots that grow beyond the deflection point are typically much smaller in diameter than the deflected root (Gilman and Paz 2013). Sudden reductions in root diameter from root deflections (Gilman and Masters 2010) and at branch points (Coutts 1983) are a source of leeward hinge points in root-soil plates when trunks are subject to lateral forces such as winching or wind. Stability may be improved by reducing these deflections inside the root ball, and planting root balls containing a large number of roots that either stop elongating or branch once they meet the container wall.

Because straight lateral roots appear to be associated with well-anchored trees planted from propagation containers (Salonius et al. 2000), the main goal of the present study was to determine the influence of root form in a container root ball on root attributes and anchorage one growing season after planting into landscape soil. Swietenia mahagoni (L.) Jacq. (mahogany) was chosen due to its popu- larity as urban landscape trees in tropical and subtropical regions of Florida, U.S., and the Caribbean.

\section{MATERIALS AND METHODS}

February 2009 seeds of Swietenia mahagoni were germinated in two propagation containers with different wall attributes ( $\mathrm{EP}=$ Elle pots or $\mathrm{SM}=$ smoothsided) and retained for 12 months (as described in Gilman and Paz 2014). Root balls on 80 trees from each propagation container were root pruned (shaved) as they were shifted in February 2010 into $3.8 \mathrm{~L}$ containers with different wall attributes $(\mathrm{SC}=$ smooth-sided black plastic, $19 \mathrm{~cm}$ top diameter $\times 19 \mathrm{~cm}$ tall, model PF400, Nursery Supplies, Chambersburg, Pennsylvania, 40 trees; and $\mathrm{PC}=$ black plastic container with porous sides and bottom, Pioneer pot, $19 \mathrm{~cm}$ top diameter $\times 17 \mathrm{~cm}$ tall, Pioneer Farms, Visalia, California, U.S., 40 trees) by removing the outer $5 \mathrm{~mm}$ of the liner root ball sides and bottom with sharp scissors (Fiskars, \#FSK01004342). Roots were pruned by one person to standardize procedure. Remaining 80 trees from each were not root pruned when shifted into the SC ( 40 trees) and PC (40 trees) containers. In August 2010, trees in SC and PC were shifted into larger-sized $9.5 \mathrm{~L}$ containers of the same type (SC, model PF1200, $27 \mathrm{~cm}$ top diameter $\times 24 \mathrm{~cm}$ deep; PC, $28 \mathrm{~cm}$ top diameter $\times 17 \mathrm{~cm}$ deep) and placed on ground cloth randomly in rows.

In April 2011, 10 randomly chosen trees of each treatment combination (two liners $\times$ two root pruning treatments $\times$ two $3.8 \mathrm{~L}$ then $9.5 \mathrm{~L}$ containers $\times$ 10 trees $=80$ trees) were planted into field soil [Millhopper fine sand (loamy, silicaceous, hyperthermic Grossarenic Paleudults)] with less than 2\% organic matter) in Gainesville, Florida. Trunk diameter $($ mean $=14 \mathrm{~mm})$ and tree height $($ mean $=111 \mathrm{~cm})$ were recorded at planting. Top of the root ball was positioned even with surrounding soil, and trees were placed $0.9 \mathrm{~m}$ apart within three rows spaced $2 \mathrm{~m}$ apart. Some main roots emerged from the trunk base within $1 \mathrm{~cm}$ of the substrate surface. No root manipulation was performed at planting. One tree from each treatment combination was randomly assigned to a block of eight trees for a total of 10 blocks. A $0.5 \mathrm{~m}$ diameter circular soil area around each tree was irrigated with $8 \mathrm{~L}$ through a Roberts spray stake (Model SS-AG160BLK-100), which was divided into three daily applications to encourage rapid growth. Fertilizer $\left(20 \mathrm{~N}, 0 \mathrm{P}_{2} \mathrm{O}_{5}, 8 \mathrm{~K}_{2} \mathrm{O} ; 65 \mathrm{~g}\right.$ in April, $120 \mathrm{~g}$ in June and August 2011) was applied to a $50 \mathrm{~cm}$ 
diameter circular area around each tree. Shoots were not pruned at or after planting. A wood chip (utility pruning waste) mulch layer $10 \mathrm{~cm}$ thick was placed across the whole plot, almost up to the trunk, and glyphosate was applied periodically for weed control.

In November 2011, all 80 trees were winched with a hand crank that was crafted of a bent steel rod to evaluate lateral stability. No rain occurred during the three days required to pull trees. A force transducer (Model SSM-BYJ-50, 22.7 Kg, Interface Scottsdale, Arizona, U.S., non-repeatability- $\pm 0.02 \% \mathrm{RO}$ ) was placed in line with a non-stretch string secured around the tree with a tightened zip tie at $20 \mathrm{~cm}$ from the ground. Trees were pulled at a rate of approximately $10 \mathrm{~mm} \cdot \mathrm{sec}^{-1}$ once in the NE, NW, SE, and SW compass directions to a bending stress $(\sigma)$ of $4.1 \mathrm{MN} /$ $\mathrm{m}^{2}$ calculated individually for each tree from trunk diameter measured $10 \mathrm{~cm}$ from the ground using Equation 1. This slow, winching rate allowed researchers to pull at the targeted bending stress. This bending stress was chosen so that the trunk nearly returned to the pre-pulling start angle following practice winching, on extra trees from the same group planted nearby, indicating slight root or soil failure. During winching tests, load was sampled at $2 \mathrm{~Hz}$ using a 16-bit data acquisition system (National Instruments Corporation, Austin, Texas, U.S.) and displayed and archived in real-time on the laptop running LabView software (v: 7.0; National Instruments, Austin, Texas, U.S.). Trunk angle was recorded just prior to each winching by placing a digital level $(18 \mathrm{~cm}$ long, M-D SmartTool Angle Sensor Module 92346) accurate to the tenth of a degree on the bottom $18 \mathrm{~cm}$ of trunk on the side opposite the hand crank (windward). A fifth and final winching to the SW applied a bending stress of $13.8 \mathrm{MN} / \mathrm{m}^{2}$. With the tree held in position after each of the five winchings, the angle under tension and the rest angle following release of the winching string were recorded. The pre-winching trunk angle was subtracted from these angles to calculate change in angle as a result of winching.

[1] $\quad \sigma=\frac{F \cdot d \cdot R}{\frac{\pi}{4} \cdot R^{4}}$

where $\sigma=$ bending stress; $F=$ pulling force; $\mathrm{d}=$ distance from pulling point to inclinometer; and $\mathrm{R}=$ trunk radius (calculated as halving diameter measured with a diameter tape).
All 80 trees were dug up in December 2011 following winching, using a square-tipped shovel forming a circular root ball $40 \mathrm{~cm}$ across and 40 $\mathrm{cm}$ deep shaped in a cone typical of a tree dug from a field nursery. This shape and volume was large enough to harvest the planted $9.5 \mathrm{~L}$ container root ball intact. Soil and container substrate were washed from roots. Roots were measured for many attributes described in the appropriate tables. Root diameter was measured to 0.1 $\mathrm{mm}$; root depth was measured to the nearest $\mathrm{mm}$.

\section{Statistical Analysis}

Root and shoot attributes and bending stress on planted trees in December 2011 were analyzed in a three-way complete factorial analysis of variance (ANOVA) with the main effects propagation container type (2), root pruning (2), and larger-container wall attributes (2) using 10 replicates each (total 80 trees) in a randomized complete block design using the GLM procedure of SAS (version 9.2 SAS Institute, Cary, North Carolina, U.S.). Duncan's multiple range test was used to separate main effect means; interaction means were compared with Least Squares (LS) means at $P<0.05$. Pearson's correlation coefficient was used to relate root attributes to bending stress.

\section{RESULTS AND DISCUSSION}

Root pruning liners, when shifting into $3.8 \mathrm{~L}$ containers, did not impact aboveground growth after landscape planting; however, two measured root attributes were affected. Shaving liners increased cross-sectional area (CSA, calculated from diameter measured just beyond trunk) of straight roots equally for both propagation containers (Table 1). Shaving liners grown in EP had no influence on CSA of deflected roots because there were few deflected roots to remove (Gilman and Paz 2014); however, shaving SM liners dramatically reduced deflected root CSA compared to not shaving (Table 1) as with red maple (Acer rubrum L., Gilman et al. 2012). Reported effects on crown growth from manual root pruning of trees planted from propagation containers into field soil vary in the literature. Some authors found reduced crown growth (Arnold and Young 1991), no effect (Persson 1978; Gilman and Wiese 2012), or greater growth (Krasowski and Owens 2000) following root pruning at planting. Although trunk angle during winching was not impacted by root pruning the lin- 
er in the current study (data not shown), anchorage on other species has been compromised when roots deformed from growing in propagation containers were not corrected at planting (Sibley and Seaby 1982; Balisky et al. 1995). Deflections down or around the propagation container in the current study may not have been severe enough to influence stability because trees were retained in propagation containers for only 12 months. Some nurseries retain trees longer.

Although trunk diameter increased in the landscape most for trees propagated in EP and then shifted to PC, the 3-4 $\mathrm{mm}$ difference might be imperceptible (Table 2). There was also no tree height response due to liner or larger container wall attributes (data not shown), indicating little impact on growth for the first seven months after landscape planting from root form imposed by containers.

Trunk angle during winching in the initial direction (NE) at $4.1 \mathrm{MN} / \mathrm{m}^{2}$ was not different among treatments; however, trunk rest angle following winching was greatest (least stable, 0.7 degrees) for the treatment combination with the most root CSA $\left(653 \mathrm{~mm}^{2}\right.$, which was about 2 to 15 times greater than other treatments) deflected by the $9.5 \mathrm{~L}$ container (i.e., those grown in EP liners then shifted to SC containers, Table 2). This was likely due to roots dislodging permanently within the root ball, and could be explained by EP containers sending roots more laterally (44 degrees from horizontal, Table 3 ) than downward (52 degrees for SM), forcing more to grow into the $9.5 \mathrm{~L}$ sidewall. This was also described for red maple (Gilman et al. 2012), implying that a liner with a desirable root system shifted to a larger container with smooth walls resulted in a poor $9.5 \mathrm{~L}$ root system. In contrast, the large imprint resulting from deflection by the SM liner (3.2, Table 3) appeared to have a lesser impact on anchorage because root CSA deflected by liner was about 5 times greater $\left(487 \mathrm{~mm}^{2}\right.$, or $30 \%$ of the CSA in the five largest roots, Table 2) in the SM/SC treatment combination than all others (which had $\leq 7 \%$ deflected) with no difference in winching-trunk angle. The new roots initiated near the flare after liners were shifted to larger containers (Gilman and Paz 2014; Figure 1) helped trees overcome the potential instability associated with the large deflections that occurred within the liner.

Table 1. Interaction of propagation container with root pruning on CSA of straight and deflected roots seven months after planting from $9.5 \mathrm{~L}$ containers.

\begin{tabular}{llll}
\hline $\begin{array}{l}\text { Propagation } \\
\text { container (liner) }\end{array}$ & Root prune & $\begin{array}{l}\text { CSA of straight } \\
\operatorname{roots}^{\mathrm{y}}\left(\mathrm{mm}^{2}\right)\end{array}$ & $\begin{array}{l}\text { CSA (\% total CSA) of roots that were } \\
\text { both deflected }>60 \text { degrees by liner } \\
\text { and among the } 5 \text { largest }\left(\mathrm{mm}^{2}, \%\right)\end{array}$ \\
\hline EP & $\begin{array}{l}\text { None } \\
\text { Shaved }\end{array}$ & $812 \mathrm{~b}^{\mathrm{x}}$ & $72(5) \mathrm{b}$ \\
$\mathrm{SM}$ & $\begin{array}{l}\text { None } \\
\text { Shaved }\end{array}$ & $982 \mathrm{a}$ & $72(6) \mathrm{b}$ \\
& $721 \mathrm{~b}$ & $402(24) \mathrm{a}$ \\
$158(11) \mathrm{b}$
\end{tabular}

${ }^{\mathrm{z}}$ Liners were root pruned by removing the peripheral $5 \mathrm{~mm}$ (shaved) with sharp scissors, or not, as they were shifted into $3.8 \mathrm{~L}$ containers.

y Straight roots were those $>3 \mathrm{~mm}$ diameter (measured at the edge of the dug root ball) that grew from trunk into field soil (following the largest at forks) at $<45$ degree angle to the soil surface without making a turn $>60$ degrees relative to azimuth of the parent root at trunk. CSA calculated from diameter measured just beyond trunk.

${ }^{\mathrm{x}}$ Means in a column with a different letter were statistically different at $P<0.05 ; \mathrm{n}=18$ averaged across $3.8 \mathrm{~L}$ and $9.5 \mathrm{~L}$ containers; no interactions with $3.8 \mathrm{~L}$ and 9.5 L containers were significant for these two attributes.

Table 2. Interaction of propagation container with 3.8 and $9.5 \mathrm{~L}$ container on trunk rest angle, trunk diameter, and selected root attributes on trees planted 7 months earlier.

\begin{tabular}{|c|c|c|c|c|c|c|c|}
\hline $\begin{array}{l}\text { Propagation } \\
\text { container } \\
\text { (liner) }\end{array}$ & $\begin{array}{l}3.8 \mathrm{~L} \text { and } \\
9.5 \mathrm{~L} \\
\text { container }^{2}\end{array}$ & $\begin{array}{l}\text { Trunk rest angle } \\
\text { after applying } 4.1 \\
\mathrm{MN} / \mathrm{m}^{2} \mathrm{NE} \\
\text { (degrees) }\end{array}$ & $\begin{array}{l}\text { Trunk diameter } \\
10 \mathrm{~cm} \text { from } \\
\text { ground when } \\
\text { winched }(\mathrm{mm})\end{array}$ & $\begin{array}{l}\text { Trunk diameter } \\
\text { increase after } \\
\text { field planting } \\
(\mathrm{mm})\end{array}$ & $\begin{array}{l}\text { End minus start } \\
\text { angle of the five } \\
\text { largest roots } \\
\text { (degrees) }\end{array}$ & $\begin{array}{l}\text { CSA in the five largest } \\
\text { roots deflected by } 9.5 \mathrm{~L} \\
\text { container }{ }^{\mathrm{w}}\left(\mathrm{mm}^{2}\right)\end{array}$ & $\begin{array}{l}\% \text { total CSA in } \\
\text { the five largest } \\
\text { roots deflected } \\
\text { by liner }(\%)\end{array}$ \\
\hline \multirow[t]{2}{*}{$\overline{\mathrm{EP}}$} & PC & $0.3 b^{v}$ & $28.3 \mathrm{a}$ & $16.3 \mathrm{a}$ & $13.6 \mathrm{a}$ & $43 c$ & $4 \mathrm{~b}$ \\
\hline & SC & $0.7 \mathrm{a}$ & $28.3 \mathrm{a}$ & $12.8 \mathrm{~b}$ & $-18.4 c$ & $653 a$ & $7 \mathrm{~b}$ \\
\hline \multirow[t]{2}{*}{ SM } & PC & $0.3 \mathrm{~b}$ & $25.1 \mathrm{~b}$ & $12.1 \mathrm{~b}$ & $1.5 \mathrm{ab}$ & $55 \mathrm{c}$ & $6 \mathrm{~b}$ \\
\hline & SC & $0.4 \mathrm{~b}$ & $29.0 \mathrm{a}$ & $12.5 \mathrm{~b}$ & $-6.7 b c$ & $352 \mathrm{~b}$ & $30 a$ \\
\hline
\end{tabular}

${ }^{z}$ Trees were shifted from liners into $3.8 \mathrm{~L}$ and then into $9.5 \mathrm{~L}$ containers.

y Angle of trunk base relative to vertical start position immediately following release of winching cable pulled toward the northeast.

${ }^{\mathrm{x}}$ End angle $=$ angle from horizontal measured on the terminal $5 \mathrm{~cm}$ long root segment at dug root ball edge of the five largest roots (measured at trunk) following the largest at forks minus angle of the $5 \mathrm{~cm}$ long segment starting at trunk; negative number indicates roots grew up into substrate of the $3.8 \mathrm{~L}$ and $9.5 \mathrm{~L}$ container.

w Total CSA of roots that were among the five largest-diameter roots (measured at trunk) and were deflected by $9.5 \mathrm{~L}$ container walls.

${ }^{v}$ Means in a column with a different letter were statistically different at $P<0.05 ; \mathrm{n}=18$ averaged across root pruning when shifting liners to $3.8 \mathrm{~L}$ containers; no interactions with root pruning were significant for these two attributes. 


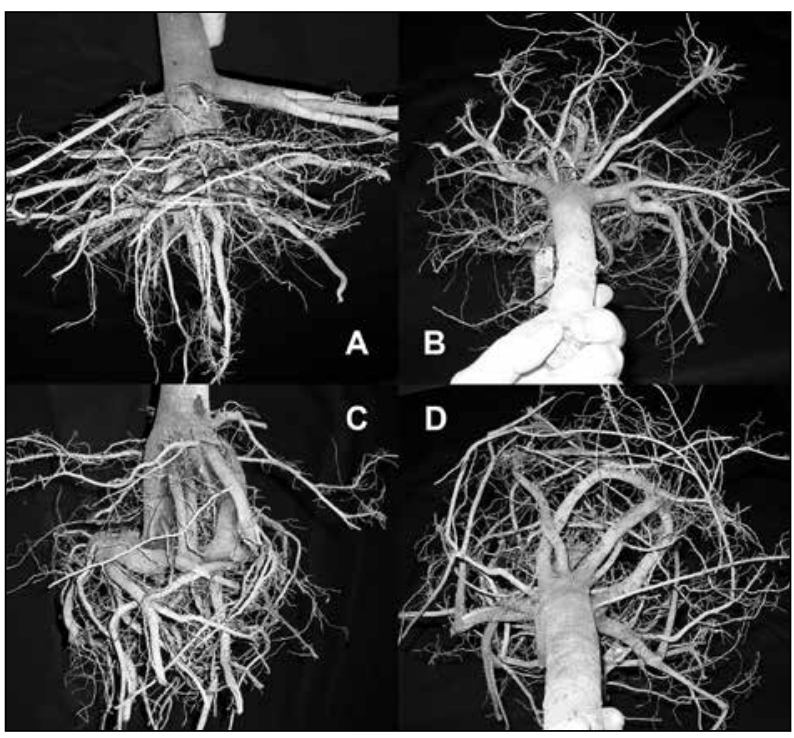

Figure 1. Four root systems from mahogany grown in the field for seven months after planting from a PC (A, B) or SC (C, D) container. Note the prominent imprint on the root system and vertical orientation of structural roots associated with poor anchorage (SC container, bottom) and little imprint and horizontal orientation associated with better anchorage (PC container, top).

Roots grew into landscape soil primarily from existing root tips in all treatments. Roots occasionally grew from segments behind the root tip in seemingly unpredictable places. Roots rarely grew after field planting from the oldest portions of the root system, including the basal $30 \mathrm{~mm}$ of the largest diameter roots deflected by container walls-as judged by a consistent color of these new roots (not measured) - which explains the long, curved segments of circling roots lacking lateral roots (Figure 1). Rarely produced were roots that grew from bends caused by a large root deflecting at the container wall, and when produced they were much smaller than the parent root. It was not clear if these small roots would become major roots on the tree.

Propagating in EP and then shifting to either of the larger containers resulted in increased CSA of straight roots (Table 3), similar to red maple in containers (Gilman et al. 2012). Roots on trees in SM liners angled downward 52 degrees (Table 3 ) before redirecting sharply upward as they grew out from the liner as shown by the negative end-minus-start angle values of the five largest roots (Table 2). This form is unlike the natural habit of tree roots (Lyford and Wilson 1964). Compared to trees in SC, trees in PC had shallower (Table 4) and straighter (Table 5 ) roots in both the trees grown on containers for this study (Gilman and Paz 2014), and at the edge of the dug root system seven months after landscape planting. This indicated that the more horizontal root system generated in the original planted 9.5 L container root ball continued developing in this fashion once in the landscape. In addition to aiding container growers, roots growing at a shallow angle to the soil surface that were fairly straight could help growers that propagate by direct seeding into field soil reach their goal of producing roots closer to the soil surface (Hewitt and Watson 2009). Under current practices many species can develop a deeper root system with fewer shallow roots than desired.

Trees planted into field soil from PC propagated in either liner tilted at a lesser angle under both bending stresses and immediately following pulling (rest angle) than trees from SC containers (Table 4). Trees that tilted less had a smaller root ball circumference lacking large roots (80 degrees), seven times the CSA in straight roots, one-third the change in root azimuth direction from trunk origin to root ball edge, more root CSA, and shallower roots (Table 4) than the less stable SC trees. Also associated with the less stable trees was greater visible root system imprint from the containers resulting in an eight-fold increase in cull root systems (Anonymous 1998) and a 2.5 -fold increase in percent trunk circled by roots. Number of straight roots was dramatically increased (eight-fold) as was root ball symmetry (2.5-fold increase) in trees more resistant to overturning (PC) and there were fewer roots growing tangent to the trunk (Table 5). Neither container eliminated circling roots or those growing tangent to the trunk.

Roots of other species that deflected downward in containers often grew out the bottom after planting into soil, resulting in artificially deep and deformed roots under the trunk (Sibley and Seaby 1982; Balisky et al. 1995; Salonius et al. 2000). Deflection of main roots downward forces them to grow parallel to one another and touch directly under the trunk (as in SC in the current study, Table 6) causing constrictions and inclusions that restrict passage of substances through vascular tissue (Lindström and Rune 1999). Distributing root tips in the lateral (horizontal) position throughout the root ball profile on young mahogany instead of at the bottom (Gilman and Paz 2014 ) allowed lateral roots to grow in a more natural straight position (Figure 1; Table 6). Lindström and Rune (1999) and others also showed that trees 
became more stable after planting when some roots were able to grow in a more horizontal orientation instead of being deflected downward or around.

Attributes of the five largest roots are important for stability because Coutts (1986), Gilman and Grabosky (2011), and others showed that the largest several roots can comprise $70 \%$ or more of the root system CSA. Despite a $15 \%(P=0.03)$ smaller CSA in the five largest roots (Table 6), trees from PC were better anchored than trees from SC. This demonstrates the large role played by root morphology. Improved anchorage was likely due to a small percentage $(23 \%)$ of roots deflected, little root contact $(13 \%)$ with adjacent roots, and five times the number of straight or branched roots on trees from PC than from SC (Table 6). Other studies appear to support these findings. For example, large, shallow, straight roots on red maple planted from $11 \mathrm{~L}$ and $95 \mathrm{~L}$ containers were at least partially responsible for better stability compared to trees planted from much larger containers $(230 \mathrm{~L}$ and 983 L, Gilman et al. 2013). Although others (Fourcaud et al. 2008; Gilman and Wiese 2012) also showed that shallow lateral roots with developing sinkers on young trees contribute substantially to overturning resistance, this is by no means a universal theorem, as both Khuder et al. (2007) and
Mickovski and Ennos (2002) found deeper rooting associated with better anchorage, especially on deep soils. Symmetrical root systems may be most important in shallow soils where trees form a platelike root system (Coutts 1983; Danjon et al. 2005).

Other techniques have been employed to develop lateral roots close to the surface. For example, trees produced in a nearly wall-less container (Jiffy pellets Jiffy, Jiffy Products of America, Inc., 600 Industrial Pkwy., Norwalk, Ohio, U.S.) or in copper-treated containers (Chapman and Colombo 2006) had more root tips and straighter lateral roots growing close to the substrate surface compared to containers that deflect roots down. Although this can enhance stability in the early years after planting, plantation trees installed from propagation containers can become better anchored with time as roots develop compensatory growth in response to mechanical stress (Lindström and Rune 1999). Furthermore, a symmetrical root system may not be as important on soils that promote deep rooting (Coutts et al. 1999).

Trunk tilt during winching to $4.1 \mathrm{MN} / \mathrm{m}^{2}$ bending stress was correlated with several attributes of root morphology inside the root ball (Table 7). Increasing the deflected nature of the root system and reducing the number of straight roots lead to greater trunk tilting. This analysis also showed that

Table 3. Effect of propagation container on root ball attributes at trunk.

\begin{tabular}{|c|c|c|c|}
\hline $\begin{array}{l}\text { Propagation } \\
\text { container (liner) }\end{array}$ & Liner imprint ${ }^{z}(1-5)$ & $\begin{array}{l}\text { Angle relative to horizontal of } \\
\text { five largest diameter roots (degrees) }\end{array}$ & Total CSA of straight ${ }^{y}$ roots \\
\hline $\mathrm{EP}$ & $0.9 \mathrm{~b}^{\mathrm{x}}$ & $44 \mathrm{~b}$ & $1058 \mathrm{a}$ \\
\hline SM & $3.2 \mathrm{a}$ & $52 \mathrm{a}$ & $790 \mathrm{~b}$ \\
\hline
\end{tabular}

${ }^{\mathrm{z}} 1$ = no visible deflection or retained "cage" formed by deflected roots at the position of the propagation liner; $5=$ highly visible "cage" formed by deflected roots at the liner.

y Straight roots (>3 mm diameter measured at the edge of the dug root ball) were those that grew from trunk into landscape soil (following the largest at forks) without making a turn of more than 60 degrees relative to azimuth of the parent root at trunk; CSA calculated from diameter measured just beyond trunk.

${ }^{x}$ Means in a column with a different letter were statistically different at $P<0.05 ; \mathrm{n}=36$ averaged across $3.8 \mathrm{~L}$ and $9.5 \mathrm{~L}$ containers and root pruning; no interactions with $3.8 \mathrm{~L}$ and $9.5 \mathrm{~L}$ containers or root pruning were significant for these three attributes.

Table 4. Effect of $3.8 \mathrm{~L}$ and $9.5 \mathrm{~L}$ container on trunk angle, trunk rest angle, and root attributes (roots $>3 \mathrm{~mm}$ diameter) at the edge of dug root ball.

\begin{tabular}{|c|c|c|c|c|c|c|}
\hline $\begin{array}{l}3.8 \mathrm{~L} \text { and } 9.5 \mathrm{~L} \\
\text { container }\end{array}$ & $\begin{array}{l}\text { Trunk angle } \mathrm{e}^{\mathrm{z}} \text { at } \\
4.1 \mathrm{MN} / \mathrm{m}^{2} \\
\text { bending stress } \\
\text { (degrees) }\end{array}$ & $\begin{array}{l}\text { Trunk angle (and } \\
\text { rest angle }{ }^{\mathrm{y}} \text { ) at } \\
13.8 \mathrm{MN} / \mathrm{m}^{2} \\
\text { bending stress } \\
\text { (degrees) }\end{array}$ & $\begin{array}{l}\text { Circumference of } \\
\text { root ball without } \\
\text { roots }>3 \mathrm{~mm} \\
\text { diameter (degrees) }\end{array}$ & $\begin{array}{l}\text { Total CSA at trunk } \\
\text { of straight roots } \\
\left(\mathrm{mm}^{2}\right)\end{array}$ & $\begin{array}{l}\text { Depth to roots at } \\
\text { edge of dug root } \\
\text { ball }(\mathrm{mm})\end{array}$ & $\begin{array}{l}\text { Azimuth angle difference } \\
\text { between end } 5 \mathrm{~mm} \text { root } \\
\text { segment and parent } 5 \mathrm{~mm} \\
\text { segment at trunk (degrees) }\end{array}$ \\
\hline $\mathrm{PC}$ & $2.1 \mathrm{~b}^{\mathrm{w}}$ & $17.7(4.1) \mathrm{b}$ & $80 \mathrm{~b}$ & $1414 \mathrm{a}$ & $130 \mathrm{~b}$ & $30 \mathrm{~b}$ \\
\hline SC & $2.5 \mathrm{a}$ & $27.2(10.2) \mathrm{a}$ & $137 \mathrm{a}$ & $203 \mathrm{~b}$ & $196 \mathrm{a}$ & $89 a$ \\
\hline
\end{tabular}

${ }^{\mathrm{z}}$ Mean trunk angle relative to vertical start position from winching in four compass directions per tree.

y Trunk angle relative to vertical start position after release of the winch.

${ }^{x}$ Straight roots were those that grew from trunk into landscape soil at $<45$ degrees from soil surface without making a turn of more than 60 degrees relative to azimuth of the parent root at trunk.

${ }^{w}$ Means in a column with a different letter were statistically different at $P<0.05 ; \mathrm{n}=36$ averaged across propagation container and root pruning; no interactions with propagation container or root pruning were significant for these six attributes. 
Table 5. Effect of 3.8 L and 9.5 L container on growth and root attributes on trees planted seven months earlier.

\begin{tabular}{|c|c|c|c|c|c|c|c|c|c|c|}
\hline $\begin{array}{l}3.8 \mathrm{~L} \text { and } 9.5 \mathrm{~L} \\
\text { container }^{2}\end{array}$ & $\begin{array}{l}\text { Trunk diam. } \\
(\mathrm{mm})\end{array}$ & $\begin{array}{l}\text { Trunk diam. } \\
\text { increase } \\
(\mathrm{mm})\end{array}$ & Height $(\mathrm{cm})$ & Imprint ${ }^{y} 3.8 \mathrm{~L}$ & Imprint $^{y} 9.5 \mathrm{~L}$ & $\%$ Cull $^{\mathrm{x}}$ & $\begin{array}{l}\% \text { trunk } \\
\text { circled } \\
\text { by rootsw }\end{array}$ & $\begin{array}{l}\text { No. straight }{ }^{v} \\
\text { roots }\end{array}$ & $\begin{array}{l}\text { Root symmetry } \\
(1-5)\end{array}$ & $\begin{array}{l}\text { No. tangent } \\
\text { roots }^{t}\end{array}$ \\
\hline PC & $26.8 \mathrm{~b}^{\mathrm{z}}$ & $14.1 \mathrm{a}$ & $195 \mathrm{~b}$ & $2 \mathrm{~b}$ & $1 \mathrm{~b}$ & $8 \mathrm{~b}$ & $15 \mathrm{~b}$ & $8 \mathrm{a}$ & $5 \mathrm{a}$ & $0.6 \mathrm{~b}$ \\
\hline SC & $28.6 \mathrm{a}$ & $12.6 \mathrm{~b}$ & $209 a$ & $5 \mathrm{a}$ & $3 a$ & $65 a$ & $6 a$ & $1 \mathrm{~b}$ & $2 \mathrm{~b}$ & $1.7 \mathrm{a}$ \\
\hline
\end{tabular}

${ }^{z}$ Trees were shifted from liners into $3.8 \mathrm{~L}$ then into $9.5 \mathrm{~L}$ containers.

y $1=$ no visible deflection or retained "cage" formed by deflected roots at the position of the propagation liner; $5=$ highly visible "cage" formed by deflected roots at the liner.

${ }^{x}$ Root cull according to Florida Grades and Standards for Nursery Plants (Anonymous 1998).

${ }^{w}$ Roots greater than $3 \mathrm{~mm}$ diameter.

${ }^{v}$ Straight roots ( $>3 \mathrm{~mm}$ diameter measured at the edge of the dug root ball) were those that grew from trunk into landscape soil (following the largest at forks) at $<45$ degrees from soil surface without making a turn of more than 60 degrees relative to azimuth of the parent root at trunk.

" Visual rating, 1 = asymmetrical and one sided; $5=$ symmetrical.

${ }^{\mathrm{t}}$ Roots growing tangent to trunk.

${ }^{s}$ Means in a column with a different letter were statistically different at $P<0.05 ; \mathrm{n}=36$ averaged across propagation container and root pruning; no interactions with propagation container or root pruning were significant for these attributes.

Table 6. Effect of $3.8 \mathrm{~L}$ and $9.5 \mathrm{~L}$ container on deflection of the five largest diameter roots (measured at the trunk).

\begin{tabular}{|c|c|c|c|c|}
\hline $\begin{array}{l}3.8 \mathrm{~L} \text { and } 9.5 \mathrm{~L} \\
\text { container }\end{array}$ & $\begin{array}{l}\text { Total root CSA } \\
\left(\mathrm{mm}^{2}\right)\end{array}$ & $\begin{array}{l}\% \text { roots deflected by } \\
3.8 \mathrm{~L} \text { or } 9.5 \mathrm{~L} \text { container }\end{array}$ & $\begin{array}{l}\% \text { roots that touched another } \\
\text { root that was also among the } \\
\text { five largest }\end{array}$ & $\begin{array}{l}\text { No. of straight or branched } \\
\text { roots at } 3.8 \mathrm{~L} \text { and } 9.5 \mathrm{~L} \\
\text { container positions }\end{array}$ \\
\hline PC & $1308 b^{y}$ & $23 \mathrm{~b}$ & $13 \mathrm{~b}$ & $5 a$ \\
\hline SC & $1531 \mathrm{a}$ & $94 \mathrm{a}$ & $86 \mathrm{a}$ & $1 \mathrm{~b}$ \\
\hline
\end{tabular}

Table 7. Significant ${ }^{2}$ Pearson correlation coefficients between trunk angle while winching to $4.1 \mathrm{MN} / \mathrm{m}^{2}$ bending stress in the direction that resulted in the highest correlation with root attributes (roots $>3 \mathbf{m m}$ diameter) of the dug root ball for mahogany grown in either SC or PC $3.8 \mathrm{~L}$ and $9.5 \mathrm{~L}$ containers.

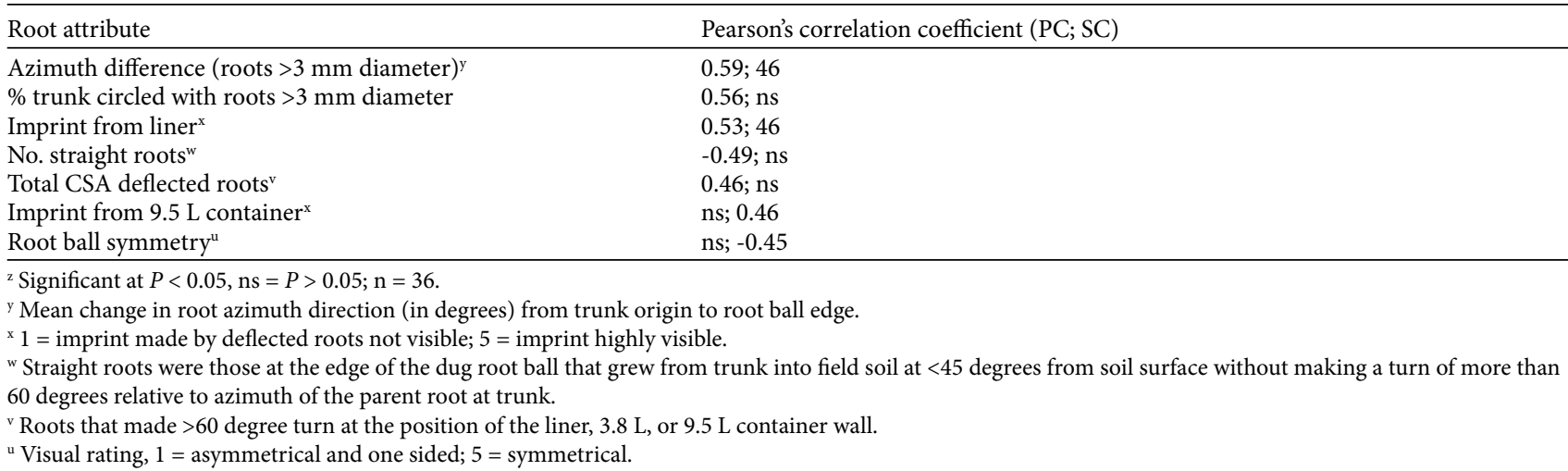

visual estimates, such as imprint from the container and root ball symmetry, were nearly as good at predicting anchorage as more time-consuming measurements, such as percent trunk circled and azimuth difference between the root origin and root end at the edge of the root ball. These quick visual evaluations will make it relatively simple for growers and others to gauge root system quality without time-consuming measurements. Lateral stresses applied to the trunk base in this study may not exactly represent those experienced by trees of similar size subjected to loads from ice, snow, or wind. Researchers pulled close to the ground to ensure that rotational bending stress was applied to the root system. The trunk and roots on larger trees in nature would be stiffer and the center of pressure in wind higher in the crown, resulting in different forces than those applied in this study. Although this study was not designed to assign percentage contribution from each measured root attribute to overturning, the data suggest a direction of future work. Cultural practices that increase cross- 
sectional area of roots growing straight from the root ball into the landscape soil without deflection, and/or entrain a large soil mass close to the trunk, should enhance anchorage by resisting overturning.

\section{CONCLUSIONS}

Although root forms often associated with health problems and trunk wood defects-such as circling and descending roots-can be caused by the propagation container, anchorage in the current study was more influenced by root morphology imparted by the larger container than by the propagation container. This occurred because root initiation from the flare continued after shifting liners into the $3.8 \mathrm{~L}$ containers, especially when vertical root growth was discouraged by air-pruning at the bottom. Trees with root balls containing horizontaloriented straight roots, little imprint from the container, and few deflected roots were most stable after landscape planting. Growing in a production system that 1) discourages vertical root growth very early in production, 2) extends the period of root initiation at the root flare, and 3) minimizes root deflection provides for better anchored trees seven months after planting into the landscape than trees grown with large descending and circling roots.

Acknowledgments. Thanks to the Horticultural Research Institute and GreatSouthernTreeConference.org (which included funding from the container manufacturers of the tested and other containers) for partial funding.

\section{LITERATURE CITED}

Anonymous. 1998. Florida Grades and Standards for Nursery Plants. Florida Department of Agriculture and Consumer Services, Gainesville, Florida, U.S.

Arnold, M.A., and E. Young. 1991. $\mathrm{CuCo}_{3}$-painted containers and root pruning affect apple and green ash root growth and cytokinin levels. HortScience 26:242-244.

Balisky, A.C., P. Salonius, C. Walli, and D. Brinkman. 1995. Seedling roots and forest floor: Misplaced and neglected aspects of British Columbia's reforestation effort? Forestry Chronicle 71:59-65.

Burdett, A.N. 1990. Physiological process in plantation establishment and the development of specifications for forest planting stock. Canadian Journal of Forest Research 20:415-427.

Chapman, K.A., and S.J. Colombo. 2006. Early root morphology of jack pine seedlings grown in different types of container. Scandinavian Journal Forestry Science 21:372-370.

Coutts, M.P. 1986. Components of tree stability in Sitka spruce on peaty, gley soil. Forestry 59:173-197.

Coutts, M.P. 1983. Root architecture and tree stability. Plant and Soil 71:171-188.
Coutts, M.P., C.C.N. Nielson, and B.C. Nicoll. 1999. The development of symmetry, rigidity, and anchorage in the structural root system of conifers. Plant and Soil 217:1-15.

Danjon, F., T. Fourcaud, and D. Bert. 2005. Root architecture and wind-firmness of mature Pinus pinaster. New Phytologist 168:387-400.

Ennos, A.R. 1995. Development of buttress in rainforest trees: the influence of mechanical stress. pp. 293-301. In: M.P. Coutts and J. Grace (Eds.). Wind and Trees. Cambridge Univ. Press Cambridge, UK.

Fourcaud, T., X. Zhang, and A. Stokes. 2008. Understanding the impact of root morphology on overtuning mechanisms: a model approach. Annals of Botany 101:1267-1280.

Gilman, E.F., and C. Wiese. 2012. Root pruning technique at planting impacts root growth and anchorage two years after planting. Arboriculture \& Urban Forestry 38:232-239.

Gilman, E.F., M. Paz, and C. Harchick. 2010. Root ball shaving improves root systems on seven species in containers. Journal of Environmental Horticulture 28:13-18.

Gilman, E.F., and F.J. Masters. 2010. Effect of tree size, root pruning, and production method on root growth and lateral ability of Quercus virginiana. Arboriculture \& Urban Forestry 36:281-291.

Gilman, E.F., and J. Grabosky. 2011. Quercus virginiana root attributes and lateral stability after planting at different depths. Urban Forestry \& Urban Greening 10:3-9.

Gilman, E.F., C. Harchick, D. Meador, and P. Fisher. 2012. Propagation container type, time in container, and root pruning affect root development of young Acer rubrum. Journal of Environmental Horticulture 30:150-160.

Gilman, E.F., J. Miesbauer, C. Harchick, and R.C. Beeson. 2013. Impact of tree size at planting, mulch and irrigation on Acer rubrum L. growth and anchorage. Arboriculture \& Urban Forestry 39:173-181.

Gilman, E.F., and M. Paz. 2014. Root system morphology influenced by container design, retention time, and root pruning. Arboriculture \& Urban Forestry 40:16-26.

Hewitt, A., and G.W. Watson. 2009. Bare root liner production can alter tree root architecture. Journal of Environmental Horticulture 27:99-104.

Khuder, H., A. Stokes, F. Danjon, K. Gouskou, and F. Lagane. 2007. Is it possible to manipulate root anchorage in young trees? Plant and Soil 294:87-102.

Krasowski, M.J. 2003. Root system modifications by nursery culture reflect on post-planting growth and development of coniferous seedlings. Forestry Chronicle 79:882-891.

Krasowski, M.J., and J.N. Owens. 2000. Morphological and physical attributes of root systems and seedlings growth in three different Picea glauca reforestation stock. Canadian Journal of Forest Research 30:1669-1681.

Lindgren, O., and G. Örlander. 1978. A study on root development and stability of 6 to 7-year old container plants. pp. 142-144. In: E. Van Eerden and J.M. Kinghorn (Eds.). Proc. of the Root Form of Planted Trees Symp., Victoria, B. C., Can., May 16-19, 1978. Can. For. Serv., B.C., Joint Rep. No. 8.

Lindström, A., and G. Rune. 1999. Root deformation in plantations of container-grown Scots pine trees: Effects on root growth, tree stability and stem straightness. Plant and Soil 217:29-37.

Lindström, A., C. Hellqvist, and E. Stattin. 2005. Mini Seedlings - A New Forest Regeneration System. pp. 56-58. In: The Thin Green Line: A symposium on the state-of-the-art in reforestation. 
Ontario Forest Research Institute, Ontario Ministry of Natural Resources, 1235 Queen Street East Sault Ste. Marie, Ontario, Can. P6A 2E5.

Lyford, W.H., and B.F. Wilson. 1964. Development of the root system of Acer rubrum L. Harvard Forest Paper No. 10.

Marshall, M.D., and E.F. Gilman. 1998. Effects of nursery container type on root growth and landscape establishment of Acer rubrum L. Journal of Environmental Horticulture 16:55-59.

Mickovski, S.B., and A.R. Ennos. 2002. A morphological and mechanical study of the root systems of suppressed crown Scots pine Pinus sylvestris. Trees 16:274-280.

Persson, P. 1978. Some possible methods of influencing the root development of containerized tree seedlings. Proceedings of the Symposium on Root Form of Planted Trees, Victoria, B.C. Canada. May 16-19. pp. 295-300.

Salonius, P., K. Beaton, and B. Roze. 2000. Effects of cell size and spacing on root density and field performance of containerreared black spruce. Information Report M-X-208E, Canadian Forest Service, Atlantic Forestry Centre, Frederickton, New Brunswick, Canada.

Selby, C., and D.A. Seaby. 1982. The effect of auxins on Pinus contorta seedling root development. Forestry 55:125-135.

Smith, I.E., and P.D. McCubbin. 1992. Effect of copper tray treatment on Eucalyptus grandis (Hill Ex Maiden) seedling growth. Acta Horticulture 319:371-376.

Edward F. Gilman (corresponding author)

Environmental Horticulture Department

University of Florida

Gainesville, Florida, U.S.

egilman@ufl.edu

Chris Harchick

Environmental Horticulture Department

University of Florida

Gainesville, Florida, U.S.
Résumé. La propagation en pots modifie les systèmes racinaires, ce qui affecte l'ancrage au sol après plantation dans les efforts de reboisement. Cependant, peu est connu sur le sujet sur les arbres de grande taille typiques des paysages urbains. L'objectif principal de cette étude était de déterminer le rôle de la morphologie des racines sur l'ancrage au sol après plantation et sur la croissance du Swietenia mahagoni ( L. ) Jacq., un arbre de paysage commun dans les climats chauds. Deux types de propagation en pots, deux types de pots, et lélagage des racines ont été utilisés pour imposer des morphologies différentes à l'intérieur des mottes. Lancrage a été évalué en imposant deux contraintes de flexion par treuillage pour simuler des rafales de vent. Quand la géo membrane a été déplacée dans un pot de 3.8L, l'interaction entre le type de propagation en pot et l'élagage des racines a empêché ceux-ci d'influencer réellement l'ancrage. L'inclinaison du tronc ( i.e. l'instabilité )qui a immédiatement suivi la traction était plus grande pour les arbres ayant le plus de racines CSA détournées par le pot de 9,5 L ; les arbres ayant des racines principales plus droites dans la motte étaient mieux ancrés. Les chercheurs ont trouvé sept attributs de racine, associés à l'inclinaison du tronc pendant les tests de treuillage, qui caractérisent l'ancrage. Les résultats montrent que les racines droites dans une motte sont associées à des arbres qui sont stables après leur plantation dans le sol d'un champ.

Zusammenfassung. Vermehrungscontainer beeinflussen das Wurzelsystem, welches die Verankerung nach der Verpflanzung in Wiederaufforstungsbemühungen beeinflusst, aber es ist bislang wenig bekannt über größere typische Bäume in der urbanen Landschaft. Das Hauptziel dieser Studie bestand darin, die Rolle der Wurzelmorphologie bei der Verankerung und Wachstum nach der Verpflanzung bei Swietenia mahagoni (L.) Jacq., einem häufigen Straßenbaum in warmen Klimata zu bestimmen. Zwei Vermehrungscontainertypen, zwei größere Containertypen und Wurzelschnitt wurden eingesetzt, um verschiedene Wurzelmorphologien innerhalb eines Wurzelballens zu erzielen. Die Verankerung wurde bewertet durch Zugversuche an zwei Biegepunkten, um Windkräfte zu simulieren. Die Interaktionen zwischen den Vermehrungscontainern und Wurzelschnitt, wenn die liner in 3,8 1 Container verpflanzt werden, verhinderten auch eine Beeinflussung der Verankerung. Ein Stammversagen direkt nach dem Ziehen war am größten bei Bäumen mit dem größten Wurzel CSA, die durch den 9,5 l Container abgelenkt waren. Bäume mit gerade gewachsenen Hauptwurzeln im Wurzelballen waren besser verankert. Die Forscher fanden sieben Wurzelattribute, die mit Stammversagen während des Zugversuchs zur Bewertung der Verankerung assoziiert waren. Die Ergebnisse zeigen, dass gerade Wurzeln im Wurzelballen mit stabileren Bäumen nach der Verpflanzung assoziiert sind.

Resumen. Los contenedores de propagación modifican los sistemas de raíces afectando el anclaje post- plantación en los esfuerzos de reforestación, pero poco se sabe acerca de los árboles de mayor tamaño típicos en paisajes urbanos. El objetivo principal de este estudio fue determinar el papel de la morfología del anclaje de la raíz después de la plantación y el crecimiento de Swietenia mahagoni (L.) Jacq, un árbol común en el paisaje de clima cálido. Se utilizaron dos tipos de contenedores de propagación, dos tipos de contenedores más grandes y poda de raíces para imponer diversas morfologías de raíces dentro de los cepellones. Fue evaluado el anclaje de los árboles sometiéndolos a dos tensiones para simular eventos de viento. La interacción entre la propagación entre tipos de contenedor y la poda de raíces, cuando el revestimiento se cambió a recipientes de $3,8 \mathrm{~L}$, influyó consistentemente en el anclaje. La inclinación del tronco (es decir, la inestabilidad) inmediatamente después de tensar fue mayor para los árboles con la raíz más desviada para contenedores de 9,5 $\mathrm{L}$; árboles con raíces principales rectas estuvieron mejor anclados. Los investigadores encontraron siete atributos de raíz asociados con la inclinación del tronco durante las pruebas que evaluaron el anclaje. Los resultados muestran que las raíces rectas en el cepellón se asociaron con árboles estables después de la plantación en el campo. 